\title{
Shigella flexneri
}

National Cancer Institute

\section{Source}

National Cancer Institute. Shigella flexneri. NCI Thesaurus. Code C86746.

A species of facultatively anaerobic, Gram negative, rod shaped bacteria in the phylum Proteobacteria. This species is oxidase and citrate negative, indole positive and can produce acid and gas from glucose. S. flexneri is a pathogen that causes shigellosis in primates. 